\title{
KEADILAN DALAM SATU (INTRA) GENERASI: SEBUAH PENGANTAR BERDASARKAN TAKSONOMI KEADILAN LINGKUNGAN
}

\author{
Andri G.Wibisana* \\ Bagian Hukum Lingkungan, Fakultas Hukum, Universitas Indonesia \\ Jalan Prof. Mr. Djokosoetono, Pd. Cina, Beji, Kota Depok, Jawa Barat, 16424
}

\begin{abstract}
This paper attempts to discuss intragenerational equity based on the taxonomy of environmental justice, i.e. distributive justice, corrective justice, procedural justice, and social justice. Based on distributive justice perspective, the paper places the polluter pays principle (PPP) and common but differentiated responsibility (CBDR) as two important legal principles in implementing intragenerational equity. Based on corrective justice perpective, the paper considers that the PPP plays an important role in implementing intragenerational equity. The paper explains the implementation of procedural justice in terms of access to participation, access to information, and legal standing. Finally, the paper observes the importance of the integration of environmental protection and social justice.
\end{abstract}

Keywords: environmental justice, sustainable development.

\section{Intisari}

Tulisan ini mencoba untuk mendiskusikan lebih mendalam keadilan intra generasi dengan menggunakan taksonomi keadilan lingkungan, yaitu keadilan distributif, keadilan korektif, keadilan prosedural, dan keadilan sosial. Secara khusus, berdasarkan perspektif keadilan distributif, tulisan ini melihat adanya kaitan erat antara keadilan intra generasi dengan polluter pays principle (PPP) dan common-but-differentiated responsibility. Dalam perspektif keadilan korektif, tulisan ini melihat pentingnya PPP untuk mewujudkan keadilan intra generasi. Tulisan ini melihat perwujudan keadilan prosedural melalui hak untuk berpartisipasi dalam pengambilan keputusan, hak atas informasi, dan hak gugat. Dalam konteks keadilan sosial, tulisan menjelaskan integrasi perlindungan lingkungan dengan penciptaan keadilan sosial.

Kata Kunci: keadilan lingkungan, pembangunan berkelanjutan.

\section{Pokok Muatan}

A. LATAR BELAKANG 393

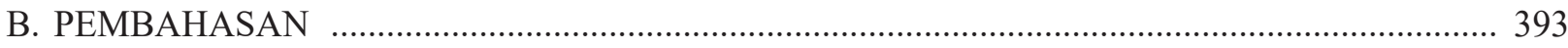

1. Keadilan Lingkungan: Diskusi tentang Terminologi ................................................................. 393

2. Keadilan Lingkungan sebagai Keadilan Distributif ............................................................. 394

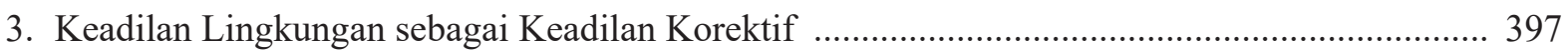

4. Keadilan Lingkungan sebagai Keadilan Prosedural ................................................................. 399

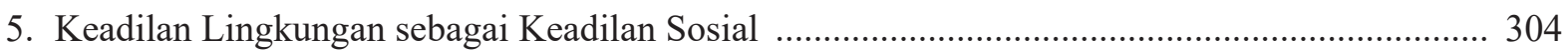

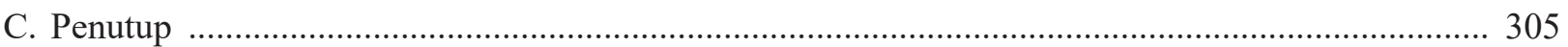

Alamat korespondensi: mragw@yahoo.com.

Tulisan ini merupakan pendalaman dan revisi atas bahan yang dibuat penulis untuk program sertifikasi hakim lingkungan yang diselenggarakan oleh Pusdiklat MA.

Penulis mengucapkan terima kasih atas komentar dari anonymous reviewer terhadap draft awal dari tulisan ini. Tentu saja kekeliruan yang ada dalam tulisan ini menjadi tanggung jawab dari penulis. 


\section{A. LATAR BELAKANG}

Pembangunan berkelanjutan dapat diturunkan menjadi beberapa elemen inti, yatu: prinsip integrasi (integration principle), prinsip pemanfaatan berkelanjutan (sustainable use), prinsip keadilan intra generasi (intragenerational equity), dan prinsip keadilan antar generasi (intergenerational equity). Tulisan ini akan memfokuskan diskusinya pada keadilan dalam satu (intra) generasi, yaitu keadilan yang ditujukan pada mereka yang hidup di dalam satu generasi. Keadilan ini terkait dengan distribusi sumber daya dan resiko secara adil, yang berlaku pada tingkat nasional maupun internasional. ${ }^{2}$ Bagi Langhelle, keadilan intra generasi merupakan prioritas pertama dari pembangunan berkelanjutan, sebagaimana ditunjukkan oleh bagian pertama dari definisi pembangunan berkelanjutan, yaitu "development that meets the needs of the present [...]". ${ }^{3}$

Tulisan ini akan menjawab pertanyaan bagaimana keadilan intra generasi ditinjau dari persepektif keadilan lingkungan. Untuk menjawab pertanyaan tersebut, tulisan ini akan mendasarkan analisisnya pada taksonomi keadilan lingkungan menurut Robert Kuehn. Selain itu, tulisan ini juga akan menjawab bagaimana aspek-aspek keadilan linkungan tersebut ditunjukkan dalam berbagai regulasi atau putusan pengadilan di Indonesia.

Tulisan ini disusun dengan struktur sebagai berikut. Bagian B.1 menjelaskan kedilan lingkungan secara umum. Bagian B.2 mendiskusikan bagaimana keadilan intra generasi dilihat sebagai keadilan distributif. Bagian B.3 membahas keadilan intra generasi sebagai keadilan korektif. Bagian B. 4 mendiskusikan keadilan intra generasi sebagai keadilan prosedural, yaitu dalam konteks hak untuk berpartisipasi dalam pengambilan keputusan, hak atas informasi, dan hak gugat. Berhubungan keterbatasan ruang, tulisan ini hanya dapat menjelaskan secara cukup mendetail terkait hak atas partisipasipasi. Bagian B.5 akan secara singkat memaparkan keadilan intra generasi sebagai keadilan sosial. Beberapa uraian kesimpulan akan dipaparkan pada Bagian C.

\section{B. PEMBAHASAN \\ 1. Keadilan Lingkungan: Diskusi tentang Terminologi}

Keadilan lingkungan bukanlah sebuah konsep yang memiliki berbagai definisi. Collin melihat keadilan lingkungan terutama dalam kaitannya dengan distribusi hak dan manfaat linkungan secara adil di antara ras, kelas, dan pendapatan masyarakat. Oleh Collin, aspek prosedural berupa partisipasi publik dalam pengambilan keputusan dianggap termasuk ke dalam hak substantif yang merupakan bagian dari keadilan distributif ini. ${ }^{4}$ Sementara itu, kalangan lainnya menganggap keadilan lingkungan tidak hanya memuat aspek distribusi, tetapi juga aspek prosedural. Hal ini misalnya dapat dilihat dari pandangan Arcioni dan Mitchell, sebagaimana dikutip oleh Millner, yang menyatakan bahwa selain terkait aspek distribusi, keadilan linkungan

Elemen-elemen ini juga dikemukakan oleh Sands, yang menyatakan bahwa elemen hukum dari pembangunan berkelanjutan terdiri atas: a). keadilan antar generasi (intergenerational equity), yang dapat dilihat dari kebutuhan untuk melindungi SDA bagi keuntungan generasi yang akan datang; b). pemanfaatan secara bekelanjutan (the principle of sustainable use), yang direfleksikan dalam eksploitasi SDA secara berkelanjutan (sustainable), hati-hati (prudent), rasional (rational), bijaksana (wise), dan layak (appropriate); c). keadilan intra generasi, yang ditunjukkan melalui pemanfaatan SDA secara berkeadilan (equitable use of natural resources), di mana pemanfaatan SDA oleh satu negara tetap harus memperhatikan kebutuhan dari negara lain; dan d). prinsip integrasi (integration principle), yang meminta adanya jaminan bahwa pertimbangan lingkungan akan diintegrasikan ke dalam rencana, kebijakan, serta program terkait ekonomi dan pembangunan, serta bahwa pemenuhan kebutuhan pembangunan harus memperhatikan tujuan perlindungan lingkungan. Lihat lebih lanjut dalam Philippe Sands, 1995, Principles of International Environmental Law: Vol. 1, Frameworks, Standards, and Implementation, Manchester University Press, Manchester, hlm. 199. Elemen yang hampir sama juga dikemukakan oleh Magraw dan Hawke yang menyatakan bahwa elemen-elemen pembangunan berkelanjutan terdiri dari: keadilan intra generasi, keadilan antar generasi, prinsip integrasi, dan kebutuhan untuk melindungi lingkungan hidup secara signifikan (the environment needs to be preserved at least to a significant degree). Lihat Daniel Barstow Magraw dan Lisa D. Hawke, "Sustainable Development", dalam Daniel Bodansky, et al., 2007, The Oxford Handbook of International Environmental Law, Oxford University Press, Oxford, hlm. 619.

Sharon Beder, 2006, Environmental Principles and Policies: An Interdiciplinary Introduction Earthscan, New York, hlm. 71.

Bagian inilah yang menunjukkan adanya komitmen dari negara-negara terhadap keadilan, termasuk redistribusi dari pihak yang kaya kepada yang miskin, baik pada level nasional maupun internasional. Lihat: Oluf Langhelle, "Sustainable Development and Social Justice: Expanding the Rawlsian Framework of Global Justice", Environmental Values, Vol. 9, No. 3, 2000, hlm. 300.

4 Robert W. Collin, "Environmental Justice in Oregon: It's The Law", Environmental Law, Vol. 38, 2008, hlm. 414. 
juga terkait dengan kesempatan publik untuk berpartisipasi dalam pengambilan keputusan terkait pengelolaan lingkungan. ${ }^{5}$

Pandangan yang melihat keadilan lingkungan lebih luas dari persoalan distribusi dan prosedural, antara lain, dapat dilihat dari pendapat Bullard. Pengarang ini mengidentifikasi lima elemen dasar dari keadilan lingkungan, yang meliputi: 1) hak individu untuk dilindungi dari pencemaran; 2) preferensi terhadap pencegahan pencemaran; 3) beralihnya beban pembuktian pada mereka yang mencemari atau mereka yang membuang limbah/emisi (dischargers) atau pada mereka yang tidak memberikan perlindungan yang sama pada kelompok minoritas; 4) bukti adanya diskriminasi dalam konteks lingkungan hidup tidak lagi diukur berdasarkan niat untuk memberikan perlakuan yang berbeda, tetapi berdasarkan adanya perbedaan dampak lingkungan yang dirasakan oleh masyarakat (disparate impacts) dan bukti statistik yang menunjukkan perbedaan itu; 5) perbedaan pembagian resiko diatasi dengan tindakan dan sumber daya yang tertarget (targeted action and resources) ${ }^{6}$

Tulisan ini sendiri menjelaskan keadilan lingkungan berdasarkan taksonomi keadilan lingkungan menurut Kuehn, di mana keadilan lingkungan dibagi ke dalam 4 kategori, yaitu keadilan lingkungan sebagai keadilan distributif, keadilan lingkungan sebagai keadilan korektif, keadilan lingkungan sebagai keadilan prosedural, dan keadilan lingkungan sebagai keadilan sosial. ${ }^{7}$ Taksonomi ini digunakan selain karena memuat aspek yang lebih luas dari sekedar keadilan distributif dan prosedural, juga karena taksonomi ini juga mampu merefleksikan prinsip keadilan yang diutarakan oleh Bullard di atas. Sub bagian selanjutnya merupakan penjelasan lebih lanjut dari penerapan keadilan lingkungan tersebut.

\section{Keadilan Lingkungan sebagai Keadilan Distributif}

Berdasarkan pendapat Dobson, sebagaimana dikutip oleh Langhelle, keadilan distributif memiliki kaitan yang sangat erat dengan pembangunan berkelanjutan karena tiga alasan, yaitu: pertama, lingkungan hidup merupakan sumber daya yang harus didistribusikan secara adil; kedua, keadilan bersifat fungsional bagi terciptanya keberlanjutan; dan ketiga, keberlanjutan juga membutuhkan adanya keadilan bagi lingkungan hidup itu sendiri. Langhelle sendiri kemudian menambahkan alasan keempat, yaitu bahwa keberlanjutan pun merupakan syarat yang dibutuhkan (necessary condition) bagi terciptanya keadilan. ${ }^{8}$

Kondisi ketidakadilan lingkungan bisa ditunjukkan dengan merujuk pada pembagian sumber daya alam dan pemanfaatan yang tidak merata, ataupun pada pembagian resiko kerusakan lingkungan yang juga tidak seimbang. Mereka yang menerima porsi terbesar dari manfaat pembangunan dan berkontribusi paling besar pada terjadinya degradasi kualitas lingkungan, justru adalah mereka yang tidak terlalu menanggung dampak dari kerusakan lingkungan. Sebaliknya, mereka yang lebih sering merasakan dampak buruk dari kerusakan lingkungan, adalah mereka yang memiliki kontribusi kecil bagi munculnya kerusakan tersebut.

Berdasarkan pandangan Beder, ketidakadilan lingkungan memiliki keterkaitan dengan berbagai faktor, di antaranya kemiskinan, kerentanan, pekerjaan, dan ras atau etnik. Menurutnya,

Felicity Millner, “Access to Environmental Justice”, Deakin Law Review, Vol. 16, No.1, 2011, hlm. 191. Hal senada juga dapat dilihat dari pandangan Ikeme dalam Jekwu Ikeme, "Equity, Environmental Justice and Sustainability: Incomplete Approaches in Climate Change Politics" Global Environmental Change, Vol. 13, 2003, hlm. 199.

Oleh Kaswan, aspek prosedural ini disebut sebagai "keadilan politis" (political justice), yang pada dasarnya merupakan keadilan (fairness) dalam pengambilan keputusan. Dalam penjelasannya mengenai keadilan politis ini, Kaswan merujuk pada pandangan Dworkin tentang "right to treatment as an equal". Lihat: Alice Kaswan, "Environmental Justice: Bridging the Gap between Environmental Laws and 'Justice", The American University Law Review, Vol. 47, 1997, hlm. 233-234.

Robert D. Bullard, "Environmnetal Justice for All”, dalam Robert D. Bullard, Environmental Justice and Communities of Color, 1994, Sierra Club Books, San Fransisco, hlm. 10.

Robert R. Kuehn, “A Taxonomy of Environmental Justice”, Environmental Law Reporter, Vol. 30, 2000, hlm. 10681.

Oluf Langhelle, Op. cit., hlm. 296. 
pencemaran lingkungan sering kali secara tidak proporsional diderita oleh mereka yang secara sosial lebih sering termarjinalkan, baik karena alasan ekonomi, jender, ras, atau pun etnik. ${ }^{9}$

Keadilan distributif lebih menuntut adanya penurunan resiko lingkungan, dibandingkan dengan adanya redistribusi resiko lingkungan. Selain itu, keadilan lingkungan juga meminta adanya pemerataan manfaat dari upaya-upaya perlindungan dan pengelolaan lingkungan yang dilakukan saat ini. ${ }^{10}$

Ketidakadilan lingkungan dapat terjadi dalam skala global, yaitu berupa ketidakadilan terhadap negara miskin/berkembang. Misalnya, negara berkembang sering kali dijadikan tujuan sebagai tempat pembuangan limbah atau berpindahnya indsustri kotor dari negara maju. ${ }^{11}$ Lebih dari itu, dalam banyak persoalan lingkungan global, seperti pemanasan global, negara berkembang seringkali merupakan pihak yang paling rentan dan paling menderita akibat dari persoalan tersebut, meskipun kontribusinya terhadap persoalan jauh lebih kecil dibandingkan dengan kontribusi negara maju. ${ }^{12}$

Keadilan distributifdalam kerangka hubungan antar negara bisa dilihat dari prinsip hukum Common-but-Differentiated Responsibility (CBDR) yaitu sebuah prinsip hukum yang menyatakan bahwa persoalan lingkungan sering kali merupakan tanggung jawab bersama, tetapi beban setiap negara atas tanggung jawab tersebut seharusnya berbedabeda. CBDR secara jelas terlihat di dalam Prinsip 6 dan 7 Deklarasi Rio 1992, yang pada satu sisi meminta agar kondisi negara berkembang, miskin, dan rentan memperoleh prioritas dalam upaya global terkait perlindungan lingkungan, dan pada sisi lain meminta agar negara maju memiliki tanggung jawab yang lebih dalam pelaksanaan upaya global terkait perlindungan lingkungan tersebut.

Menurut Weiss, CBDR memuat tiga aspek penting. Aspek yang pertama adalah aspek kebersamaan, yang oleh Weiss disebut sebagai "shared aspect". Dalam aspek ini, CBDR memuat pesan bahwa lingkungan hidup global merupakan milik bersama (commons), sehingga pada satu sisi akses terhadap lingkungan hidup tidak bisa dibatasi, dan pada sisi lain sebuah kegiatan di sebuah tempat dapat memiliki dampak lingkungan yang bersifat global. ${ }^{13}$ Aspek kedua adalah aspek kontekstual (contextual aspect), yaitu bahwa tanggung jawab bersama untuk mengatasi persoalan lingkungan perlu dibuat dengan jalan memperhatikan perbedaan tiap negara. ${ }^{14}$ Aspek ketiga adalah aspek keadilan (equity aspect), dalam arti bahwa perbedaan tanggung jawab dari tiap negara terkait dengan kontribusi dari negara tersebut atas persoalan lingkungan yang ada. ${ }^{15}$

Aspek kontekstual dan aspek keadilan di atas menunjukkan bahwa bagian terpenting dari CBDR adalah adanya pembedaan perlakuan, diferensiasi, antara negara maju dan negara berkembang. Dengan demikian, diferensiasi dapat dibenarkan secara konseptual maupun secara kontekstual. Secara konseptual, terdapat beberapa alasan untuk membenarkan adanya diferensiasi. Pertama, diferensiasi dibenarkan karena adanya perbedaan kontribusi. Alasan konseptual inilah yang terdapat

Ibid., hlm. 72-73.

10 Sharon Beder, Op. cit., hlm. 71.

11 Surat dari Larry Summers, Chief Enonomist dari Bank Dunia pada tahun 1991, dengan jelas menyatakan bahwa secara ekonomi industri kotor akan lebih efisien jika dipindahkan dari negara maju ke negara miskin. Dalam memo internal yang kemudian bocor dan menimbulkan berbagai kecaman, Summers menulis: "just between you and me, shouldn't the World Bank be encouraging more migration of the dirty industries to the LDCs [Less Developed Countries]?" Dikutip dari: James Syfers, "Human Rights versus Classical Liberalism: A Study in the Theory of Value", dalam Anatole Anton, et al., 2000, Not for Sale: In Defense of Public Goods, Westview Press, Boulder, hlm. 163-166.

12 Dalam konteks perubahan iklim, misalnya, porsi terbesar (sekitar $80 \%$ ) dari konsentrasi gas rumah kaca sebagai penyebab perubahan iklim, berasal dari negara maju. Namun demikian, negara berkembang memiliki kerentanan yang lebih tinggi terhadap dampak perubahan iklim dibandingkan dengan negara maju. Lihat: Sharon Beder, Op. cit., hlm. 74-75.

13 Edith Brown Weiss, "Common but Differentiated Responsibilities in Perspective", Proceedings of the Annual Meeting (American Society of International Law, Vol. 96, 2002, hlm. 366-367.

14 Ibid., hal. 367. Konsekuensi dari perhatian terhadap persoalan kontekstual dapat dilihat dari adanya kelonggaran yang diberikan kepada negara berkembang untuk memenuhi komitmen internasional, serta adanya bantuan terhadap negara berkembang dan peningkatan kapasitas mereka dalam rangka pemenuhan komitmen tersebut

15 Ibid., hal. 368. Dalam hal ini, aspek keadilan dari CBDR meminta agar negara yang memiliki kontribusi lebih besar bagi munculnya persoalan lingkungan memikul tanggung jawab yang lebih besar untuk mengatasi persoalan lingkungan tersebut. 
pada kalimat ketiga dari Prinsip 7 Deklarasi Rio, yang menyatakan bahwa "The developed countries acknowledge the responsibility that they bear in the international pursuit of sustainable development in view of the pressures their societies place on the global environment". ${ }^{16}$ Kedua, diferensiasi konseptual dapat dibenarkan karena sebagai pihak yang selama ini paling banyak mengambil keuntungan dari adanya eksploitasi lingkungan, negara maju selayaknya memikul porsi tanggung jawab terbesar untuk mengatasi dampak dari eksploitasi tersebut. ${ }^{17}$ Ketiga, secara konseptual diferensiasi pun dapat dibenarkan sebagai perlakuan istimewa bagi negara berkembang yang berlaku untuk sementara waktu saja. Dalam hal ini, French mengatakan bahwa dengan tingkat pencemaran di negara berkembang yang saat ini telah mencapai tingkat yang cukup tinggi, bahkan mungkin sudah melampaui tingkat pencemaran dari negara maju, maka tanggung jawab yang lebih tinggi dari negara maju tidak bisa berlangsung selamanya. ${ }^{18}$

Secara kontekstual, diferensiasi tanggung jawab dapat dibenarkan karena adanya alasan-alasan khusus yang diberikan kepada negara berkembang. Meskipun pada dasarnya bahwa tanggung jawab haruslah sama, namun mengingat kondisi dari negara berkembang, maka tanggung jawab tersebut mengalami diferensiasi sehingga negara berkembang diberikan beberapa pengecualian atau kelonggaran untuk memenuhi tanggung jawab (komitmen) yang ada. French mengemukakan beberapa alasan mengapa pembedaan kontekstual ini terjadi. Pertama, negara maju dianggap memiliki kemampuan teknologi dan keuangan yang lebih baik dibandingkan dengan negara berkembang, sehingga wajar jika negara maju memiliki tanggung jawab (komitmen) yang lebih dibandingkan dengan negara berkembang. Kedua, persoalan lingkungan yang paling dahsyat sering kali terjadi di negara berkembang, yang sayangnya memiliki kapasitas yang lemah untuk menghadapi persoalan lingkungan tersebut. Wajarlah jika negara maju memiliki kewajiban yang lebih untuk membantu negara berkembang dalam mengatasi persoalan lingkungan tersebut. ${ }^{19}$ Ketiga, perlakuan istimewa kepada negara berkembang dibenarkan karena negara berkembang belum memiliki kemampuan teknologi dan keuangan yang memadai. Dalam hal ini, bagi banyak negara berkembang, yang saat ini masih berjuang untuk mencapai kesejahteraan dan mengentaskan kemiskinan, persoalan lingkungan sering kali bukanlah merupakan persoalan yang dianggap prioritas. ${ }^{20} \mathrm{Keempat}$, diferensiasi tanggung jawab yang mengistimewakan kedudukan negara berkembang diperlukan agar negara berkembang mau terlibat dalam berbagai perjanjian lingkungan internasional. ${ }^{21}$

Diferensiasi tanggung jawab yang sering ditemukan dalam berbagai kesepakatan lingkungan dapat dikelompokkan ke dalam tiga tipe. Pertama, adalah perbedaan dalam hal komitmen (standar). Dalam hal ini, kita bisa merujuk pada konvensi tentang perubahan iklim, United Nations Framework Convention on Climate Change (UNFCCC), yang secara jelas membagi negara-negara ke dalam "Annex 1 countries" (negara maju), dan "non-Annex 1 countries" (negara berkembang). Negara Annex 1 memiliki berbagai kewajiban yang bertujuan untuk menstabilkan emisi gas rumah kaca (GRK) pada level tahun $1990,{ }^{22}$ sedangkan negara Non-Annex 1

16 Alasan ini dapat pula dilihat dari Paragraf ke-16 Bagian Pembukaan dari Resolusi Majelis Umum PBB No. 44/228 tahun 1989, yang menyatakan bahwa "the responsibility for containing, reducing, and eliminating global environmental damage must be borne by the countries causing such damage, must be in relation to the damage caused, and must be in accordance with their respective capabilities and responsibilities". Lihat: Sixteenth preambular paragraph, UNGA A/RES/44/228, 22 December 1989.

17 Duncan French, "Developing States and International Environmental Law: The Importance of Differentiated Responsibilities", The International and Comparative Law Quarterly, Vol. 49(1), 2000, hlm. 48-49.

Ibid., hlm. 49-50.

Ibid., hlm. 50-51.

Ibid., hlm. 52

Ibid., hlm. 56.

The 1992 UN Framework Convention on Climate Change, 9 May 1992 (in force 21 March 1994), 1771 UNTS 107, 31 ILM 849 (1992)selanjutnya disebut UNFCCC, dalam Pasal 4 par. $2 b$. 
dibebaskan dari kewajiban ini.

Kedua, diferensiasi juga dapat bersifat kontekstual. Dalam hal ini, French merujuk pada beberapa dokumen, seperti UNFCCC, Protokol Kyoto, Convention on Biological Diversity (CBD), Prinsip-prinsip Kehutanan tahun 1992 (1992 Forest Principles), dan United Nations Convention to Combat Desertification (UNCCD 1994), yang secara tegas memberikan perhatian khusus pada keadaan dan kebutuhan negara berkembang. Difersifikasi seperti ini merupakan pendekatan yang fleksibel terhadap persoalan lingkungan internasional dengan memberikan perhatian pada realitas ekonomi dan sosial yang ada. ${ }^{23}$

Ketiga, diferensiasi tanggung jawab dapat pula terkait dengan persoalan pendanaan. Terkait hal ini beberapa perjanjian, UNFCCC memperlihatkan kewajiban negara maju, terutama mereka yang termasuk ke dalam Annex II, untuk memberikan bantuan pendanaan dan alih teknologi terkait perubahan iklim. ${ }^{24}$ Sementarai itu, terkait perlindungan ozon, Montreal Protocol on Ozone Depleting Substances, memuat beberapa ketentuan mengenai adanya bantuan keuangan dan tekonologi dari negara maju kepada negara berkembang. ${ }^{25}$ Bentuk lain dari diferensiasi ini dapat pula terlihat dari pembentukan lembaga dana bagi perlindungan dan pengelolaan lingkungan global, yang sumber pendanaannya berasal dari negara maju. Hal ini dapat dilihat, misalnya, pada Copenhagen Green Climate Fund, yang dihasilkan dari Copenhagen Accord sebagai produk kesepakatan yang dihasilkan dari pertemuan negara anggota (Conference of Parties - COP) dari UNFCCC. Dalam hal ini, Copenhagen Accord memuat komitmen negara maju bagi pendanaan Climate Fund. ${ }^{26}$

\section{Keadilan Lingkungan sebagai Keadilan Korektif}

Keadilan korektif merupakan bentuk keadilan yang ditujukan sebagai upaya pemberian sanksi, pembebanan kewajiban pemulihan, atau kewajiban melakukan kompensasi bagi mereka yang menimbulkan kerugian pada pihak lain. ${ }^{27}$ Dalam konteks ini, mereka yang menimbulkan kerugian lingkungan (dan berarti menyebabkan ketidakadilan lingkungan) memikul tanggung jawab untuk mengembalikan dampak akibat kerugian tersebut.

Karena keadilan korektif menginginkan agar mereka yang menyebabkan terjadinya kerugian untuk memperbaiki kerugian yang terjadi, maka Adler dan Wilkinson menganggap keadilan korektif memiliki keterkaitan dengan prinsip pencemar membayar (polluter pays principle). Dalam hal ini, kedua pengarang tersebut menganggap keadilan korektif merupakan salah satu alasan pembenar bagi prinsip pencemar membayar. ${ }^{28}$

\footnotetext{
Duncan French, Op. cit., hlm. 40-41.

UNFCCC, Pasal 4, paras. 3-5.

Montreal Protocol on Substances that Deplete the Ozone Layer as Either Adjusted and/or Amended in London 1990, Copenhagen 1992, Vienna 1995, Montreal 1997 (unofficial consolidated text), Pasal 10 par. 1.

26 The Copenhagen Accord, FCCC/CP/2009/11/Add.1, Decision 2/CP.15, para. 8.

Sistem pendanaan perubahan iklim ini akhirnya terwujud dalam bentuk Green Climate Fund, yang dibentuk melalui Cancun Agreement 2010. Lihat: The Cancun Agreements: Outcome of the Work of the Ad Hoc Working Group on Long-term Cooperative Action under the Convention, FCCC/CP/2010/7/Add.1, Decision 1/ CP16, par. 102. Komitmen negara maju dalam pendanaan juga tertuang dalam Paragraf 95 dan 98 dari Cancun Agreement. Selanjutnya, komitmen ini dipertegas kembali dalam Paris Agreement 2015. Dalam hal ini, Paris Agreement secara tegas meminta negara maju untuk menyediakan pendanaan bagi negara berkembang terkait mitigasi dan adaptasi perubahan iklim. Lihat: Paris Agreement 2015, FCCC/CP/2015/10/Add.1, Decision 1/CP.21, Pasal 9, par. 1

27 Robert Kuehn, Op. cit., hlm. 10693-10694.

28 John Adler dan David Wilkinson, 1999, Environmental Law and Ethics, Mac Millan Press, London, hlm. 174.

Secara teoritis, Prinsip Pencemar Membayar pada dasarnya merupakan sebuah penerapan teori ekonomi dalam rangka pengalokasian biayabiaya pencemaran dan kerusakan lingkungan, tetapi kemudian memiliki implikasi bagi perkembangan hukum lingkungan internasional dan nasional, yaitu dalam hal terkait dengan masalah tanggung jawab ganti kerugian atau dengan biaya-biaya lingkungan yang harus dipikul oleh pejabat publik. Prinsip ini pertama-tama tercantum dalam beberapa rekomendasi OECD pada tahun 70-an yang pada dasarnya mewajibkan para pencemar untuk memikul biaya atas diambilnya upaya oleh pejabat publik guna menjaga agar kondisi lingkungan berada pada kondisi yang dapat diterima. Dengan kata lain, biaya-biaya yang diperlukan untuk menjalankan upaya ini harus tercermin di dalam harga barang dan jasa yang telah menyebabkan pencemaran dalam proses produksi atau konsumsinya. Lihat: A. Boyle, "Economic Growth and Protection of the Environment: Impact of International Law and Policy", dalam Alan Boyle, 1994, Environmental Regulation and Economic Growth, Clarendon Press, London, hlm. 179-182. Lihat juga Alan Boyle dan Patricia Birnie, 2002, International Law and the Environment $2^{\text {nd }}$ ed., Oxford University Press, Oxford, hlm. 92-95.
} 
Prinsip pencemar membayar sendiri merupakan sebuah prinsip yang ditujukan sebagai upaya untuk mendorong adanya internalisasi eksternalitas. Hal ini dapat dilihat dari Prinsip 16 Deklarasi Rio yang meminta agar setiap negara "Promote the internalization of environmental costs and the use of economic instruments, taking into account the approach that the polluter should, in principle, bear the cost of pollution [...]."

Berdasarkan perspektifekonomi, eksternalitas adalah bentuk dari kegagalan pasar (market failure), sebab pasar gagal mempertimbangkan total biaya (dalam hal ini pencemaran) yang diakibatkan oleh sebuah proses produksi. Dengan demikian, eksternalitas ini dibuktikan dengan adanya harga yang tidak mencerminkan biaya-biaya lingkungan. ${ }^{29}$ Eksternalitas memberikan arah yang salah pada individu ketika mengambil keputusan, sebab dengan adanya eksternalitas ini pasar gagal untuk mencerminkan harga yang sebenarnya dari sebuah produk atau kegiatan. ${ }^{30}$

Dalam buku teks ekonomi, pencemaran seringkali digunakan sebagai contoh klasik dari eksternalitas. ${ }^{31}$ Karenanya, berdasarkan perspektif ekonomi, hukum lingkungan terutama bertujuan untuk menginternalisasi eksternalitas (to internalize the externality). ${ }^{32}$ Proses ini dibuat untuk memaksa agar semua pihak memasukkan pertimbangan biaya lingkungan (environmental costs) ke dalam pengambilan keputusannya. Dengan cara ini konsumen diharapkan akan menghadapi harga produk yang sesungguhnya. ${ }^{33}$

Sayangnya, UU No. 32 Tahun 2009 telah mengartikan prinsip pencemar membayar secara sempit. Hal ini terlihat dari Penjelasan Pasal 87 ayat 1 UU No. 32 tahun 2009 yang menyatakan bahwa Pasal tersebut merupakan realisasi dari prinsip pencemar membayar. Karena Pasal 87 tersebut merupakan pasal tentang pertanggungjawaban perdata berdasarkan perbuatan melawan hukum (PMH), maka UU No. 32 Tahun 2009 telah menafsirkan prinsip pencemar membayar secara sempit, yaitu hanya dalam bentuk pertanggungjawaban berdasarkan kesalahan (liability based on fault), yaitu PMH.

Tentu saja hal ini mengandung konsepsi yang keliru tentang prinsip pencemar membayar. Pertama, pertanggungjawaban perdata tidak hanya meliputi PMH, tetapi juga strict liability (Pasal 88 UU No. 32 Tahun 2009), sehingga strict liability seharusnya dipandang pula sebagai perwujudan prinsip pencemar membayar. Kedua, prinsip pencemar membayar seharusnya dijadikan salah satu landasan bagi kebijakan instrumen lingkungan secara umum, yang meliputi tidak hanya pertanggungjawaban perdata tetapi juga sistem command and control (CAC), instrumen ekonomi, dan refleksif/sukarela.

Instrumen ekonomi, sebagai perwujudan prinsip pencemar membayar, dapat dilihat di dalam ketentuan Pasal 43 UU No. 32 tahun 2009. Menurut Pasal ini, instrumen ekonomi tidak hanya meliputi pajak lingkungan (Pasal 43(3) huruf b), perdagangan izin (Pasal 43(3) huruf d), atau uang jaminan (Pasal 43(2) huruf a), tetapi juga memuat instrumen sukarela seperti label dan penghargaan (Pasal 43(3) huruf g dan h), lembaga keuangan dan pasar modal yang ramah lingkungan (Pasal 43(3) huruf c), neraca lingkungan (Pasal 43(1) huruf a),

29 Eksternalitas terjadi ketika keputusan yang diambil oleh seseorang mempengaruhi keputusan dan keadaan orang lain secara langsung, tanpa melalui mekanisme pasar sebab pasar justru gagal untuk mencerminkan harga yang sebenarnya. Secera singkat, eksternalits ditandai dengan adanya perbedaan antara private costs (atau marginal costs of private production) dengan social costs (atau marginal social external costs). Lihat R.S. Pindyck and D.L. Rubinfield, 2001, Microeconomics 5th ed., Prentice Hall, New York, hlm. 592. Lihat juga Eric J. Solberg, 1982, Intermediate Microeconomics, Tex: Business Publication, Plano, hlm. 540.

30 Michael Faure dan Goran Skogh, 2003, The Economic Analysis of Environmental Policy and Law: An Introduction, Edward Elgar, Cheltenham, hlm. 95 .

Lihat misalnya: Edwin Mansfield, 1983, Principles of Microeconomics 4th ed., W.W. Norton and Company, New York, hlm. $75-76$.

Michael Faure, 2001, Environmental Law and Economics, Maastricht University, Maastricht, hlm. 10.

Secara ekonomi, harga (P) ditentukan sebesar biaya marginal (MC). Apabila terjadi eksternalitas, maka MC tidak sama dengan biaya social marjinal (MSC), karena terdapat factor biaya ekternal marjinal (MEC) yang tidak diperhitungkan. Internalisasi eksternalitas dimaksudkan agar MEC diperhitungkan, sehingga biaya marjinal menjadi MSC: $\mathrm{P}=\mathrm{MC}+\mathrm{MEC}=\mathrm{MSC}$. Lihat: D. Hunter, et al., 1998, International Environmental Law and Policy, Foundation Press, New York, hlm. 108. 
bahkan GDP hijau (Pasal 43(3) huruf b). ${ }^{34}$

\section{Keadilan Lingkungan sebagai Keadilan Prosedural}

Dworkin membagi hak ke dalam hak atas perlakuan yang sama (right to equal treatment) dan hak atas perlakuan sebagai sesuatu yang setara (right to treatment as an equal). Menurut Dworkin, right to equal treatment adalah hak untuk distribusi yang sama atas barang dan kesempatan; sedangkan right to treatment as an equal adalah hak terkait untuk memperoleh perhatian (concern and respect) yang sama dalam pengambilan keputusan politik terkait distribusi barang dan kesempatan tersebut. ${ }^{35}$ Dengan demikian, right to equal treatment adalah hak atas distribusi sumber daya yang adil, sedangkan right to treatment as an equal adalah hak terkait pengambilan keputusan yang adil untuk menjamin distribusi yang adil. Karena itulah, Kuehn menafsirkan right to equal treatment sebagai keadilan distributif, ${ }^{36}$ dan right to treatment as an equal sebagai keadilan prosedural. ${ }^{37}$ Lebih jauh lagi, Kuehn menyatakan bahwa keadilan prosedural ini memfokuskan pada proses pengambilan keputusan yang adil, dan bukan pada hasil dari pengambilan keputusan tersebut. Menurutnya, keadilan ini misalnya menuntut adanya model pengambilan keputusan yang lebih deliberatif, perlindungan kepada pihak-pihak yang dirugikan, serta adanya akses yang setara atas proses pengambilan keputusan. ${ }^{38}$ Keadilan prosedural yang dibahas di dalam Subbagian ini meliputi keadilan prosedural sebagai hak untuk berpartisipasi dalam pengambilan keputusan, hak atas informasi, dan hak gugat.

\section{a. Partisipasi dalam Pengambilan Keputusan}

Menurut Stirling, partisipasi dalam pengambilan keputusan dapat dibenarkan berdasarkan tiga alasan, yaitu alasan normatif, instrumental, dan substantif. Secara normatif, partisipasi publik adalah sesuatu yang benar untuk dilakukan (the right thing to do) di dalam masyarakat yang demokratis. Pandangan normatif ini, menurut Stirling, didasarkan pada cita-cita tentang emansipasi, keadilan sosial, dan persamaan. Secara singkat dapat dikatakan bahwa dalam perspektif normatif, partisipasi publik dalam pengambilan keputusan sudah benar dengan sendiri dan merupakan sesuatu yang harus dilakukan di dalam masyarakat yang demokratis, tanpa melihat hasil dari keputusan tersebut. ${ }^{39}$

34 Secara teoritis, Pasal 43 UU No. 32 Tahun 2009 kurang begitu tepat karena tidak hanya masih mencampuradukkan antara instrumen ekonomi dengan penaatan sukarela (voluntary compliance atau moral suation), tetapi juga bahkan menambahkan berbagai instrumen yang dalam berbagai literatur standar tentang ekonomi lingkungan sebenarnya tidak dikenal sebagai instrumen ekonomi. Sebagai perbandingan, bentuk instrumen ekonomi di negara lain dapat dilihat dalam berbagai contoh yang diberikan oleh Pearce dan Turner. Contoh tersebut antara lain adalah: pajak (termasuk effluent charge, user charge, administrative charge, dan product charge), subsidi (termasuk soft loans dan tax allowances), sistem jaminan uang (deposit-refund system), dan penciptaan pasar (termasuk tradeable permits dan liability insurance). Lihat: D.W. Pearce dan R.K. Turner, 1990, Economics of Natural Resources and the Environment, Johns Hopkins University Press, Baltimore, hlm. 172 .

35 Ronald Dworkin, 1978, Taking Rights Seriously, Harvard University Press, Cambridge, hlm. 273.

36 Robert R. Kuehn, Op. cit., hlm. 10683.

Ibid., hlm. 10688.

Ibid., hlm. 10688-9.

39 Andy Stirling, "Opening up or Closing down? Analysis, Participation and Power in the Social Appraisal of Technology", dalam M. Leach, et al., 2005, Science and Citizens: Globalization and the Challenge of Engagement, Zed Books, London, hlm. $220-221$.

40 Untuk memahami makna dari Keadilan Prosedural Murni, maka ada baiknya jika kita bandingkan keadilan prosedural ini dengan keadilan prosedural lainnya menurut Rawls, yaitu Keadilan Prosedural Sempurna (Perfect Procedural Justice) dan Keadilan Prosedural Tidak Sempurna (Imperfect Procedural Justice).

Keadilan prosedural sempurna memiliki dua karekteristik: pertama, adanya kriteria independen yang menentukan hasil atau pembagian (distribusi) yang adil. Kriteria ini ditentukan terpisah sebelum adanya prosedur mengenai hasil pembagian tersebut. Kedua, adanya prosedur yang dapat memastikan hasil/distribusi yang adil. Apabila aspek pertama terkait dengan aspek distribusi (dalam hal ini kriteria tentang pembagian yang dianggap adil), maka aspek kedua terkait dengan aspek prosedural (yaitu bagaimana mekanisme/prosedur untuk mencapai pembagian yang dianggap adil). Rawls mencontohkan keadilan prosedural sempurna dalam pembagian kue. Apabila disepakati bahwa hasil yang adil adalah setiap orang memperoleh potongan kue yang sama besarnya, maka prosedur pembagian yang dapat digunakan adalah pemotong mengambil bagiannya paling terakhir (yaitu setelah orang lain mengambil bagian mereka masing-masing). Dengan cara ini maka pemotong akan berusaha memotong kue sama besar. 
Dalam perspektif Rawlsian, pembenaran normatif ini mirip dengan gagasan Keadilan Prosedural Murni (Pure Procedural Justice). Keadilan Prosedural ini terjadi ketika kita hanya memiliki prosedur, tetapi tidak memiliki kriteria untuk menentukan hasil apa yang dianggap adil. Permainan judi merupakan contoh dari Keadilan Prosedural Murni. ${ }^{41}$ Dengan demikian dapat disimpulkan bahwa menurut perspektif Keadilan Prosedural Murni, partisipasi dalam pengambilan keputusan sudah merupakan prosedur yang adil atau benar, tanpa melihat apakah hasil (dalam hal ini keputusan) yang diambil merupakan hasil yang adil atau benar. Belum tentu partisipasi akan menghasilkan keputusan yang paling benar; tetapi keputusan yang diambil tanpa adanya partisipasi sudah pasti merupakan keputusan yang keliru.

Lebih jauh lagi, secara normatif partisipasi pun dapat dibenarkan dengan merujuk pada pembenaran berdasarkan teori diskursus sebagaimana diketengahkan oleh Solum. Dengan merujuk pada gagasan Habermas mengenai situasi komunikatif yang ideal (ideal communicative situation), Solum memperlihatkan fungsi partisipasi sebagai upaya untuk mencapai konsensus yang rasional, yaitu konsensus yang mensyaratkan adanya kesempatan yang sama bagi semua pihak terkait (participants) untuk melibatkan diri, mengemukakan, mempertanyakan dan membantah argumen atau klaim. ${ }^{42}$ Tidak ada paksaan terhadap para pihak untuk mencapai kesepakatan, sebab kekuatan satu-satunya yang diperbolehkan adalah argumentasi yang lebih baik dan satu-satunya motif yang diizinkan adalah kehendak untuk bekerja sama dalam pencarian kebenaran. ${ }^{43}$

Proses deliberasi secara instrumental dilakukan melalui perdebatan yang mendalam dan demokratis, berpotensi untuk menjaga kepercayaan publik, atau bahkan menurunkan ketidakpercayaan publik, terhadap keputusan pemerintah. Dalam hal ini, Stirling berpendapat bahwa demokratisasi proses pengambilan keputusan memiliki fungsi pragmatis, yaitu untuk memediasi perbedaan antara publik dan pakar, mengurangi ketidakpercayaan publik terhadap proses pengambilan keputusan, meningkatkan kredibilitas kebijakan publik, serta meningkatkan kepercayaan publik terhadap institusi dan prosedur pengambilan kebijakan publik. ${ }^{44}$ Beberapa penelitian

Keadilan prosedural sempurna seperti di atas pada kenyataannya sangat lah sulit, jika bukan tidak mungkin, ditemukan. Kita lebih sering mengetahui kriteria terkait salah satu aspek, yaitu hanya aspek hasil atau aspek prosedural, tetapi jarang mengetahui kedua aspek tersebut. Jika kita hanya mengetahui hasil apa yang dianggap adil, tetapi tidak memiliki prosedur untuk memastikan tercapainya hasil yang adil tersebut, maka kita sedang menghadapi situasi Keadilan Prosedural Tidak Sempurna. Contoh dari kondisi ini adalah sistem peradilan pidana. Dalam sistem ini, kita tahu bahwa hasil yang adil adalah jika pengadilan hanya akan menghukum mereka yang bersalah, dan tidak akan menghukum orang yang tidak bersalah. Akan tetapi, kita tidak memiliki prosedur yang dapat menjamin secara pasti bahwa pengadilan selalu hanya akan menghukum orang bersalah dan tidak akan menghukum orang yang tidak bersalah.

Lihat: John Rawls, 1999, A Theory of Justice, Belknap Press of Harvard University Press, Cambridge, hlm. 74-75.

41 Ibid., hlm. 75. Dalam hal ini, sepanjang para pemain tidak berbuat curang (berarti mengikuti prosedur yang telah dibuat), maka hasil apa pun selalu dianggap adil, meskipun misalnya pada akhir permainan hanya seorang pemain yang menang dan sisanya kalah.

42 Lawrence B. Solum, "Procedural Justice", Southern California Law Review, Vol. 78, 2004, hlm. 267.

43 Jurgen Habermas, 2007, Moral Consciousness and Communicative Action, Polity Press, Cambridge, hlm. 88-89.

Secara spesifik, Solum mengetengahkan ciri dari situati komunikatif yang ideal dengan mengikuti uraian Alexy tentang aturan-aturan diskursus ideal, yaitu: a). Rule of participation, di mana setiap orang yang mampu berkomunikasi dan melakukan tindakan diizinkan untuk berpartisipasi dalam diskursus; b). Rule of equality of communicative opportunity, di mana setiap orang diizinkan untuk mengajukan usulan, mempertanyakan usulan, dan untuk mengekspresikan sikap, keyakinan, harapan, atau kebutuhannya; dan c). Rule against compulsion, di mana tidak seorang pun dapat mengalami paksaan (baik eksternal maupun internal) dalam menjalankan haknya yang ada dalam huruf (a) dan (b) di atas. Lihat: Lawrence B. Solum, Op. cit., hlm. 269-270.

Pandangan Alexy yang dirujuk oleh Solum sebenarnya merupakan upaya untuk menjelaskan gagasan Habermas tentang komunikasi yang ideal. Dalam hal ini, diskursus yang ideal mensyaratkan bahwa: a). Semua pihak tanpa kecuali, sepanjang mereka memiliki kapasitas, harus dilibatkan dalam proses argumentasi; b). Semua pihak dijamin memiliki kesempatan yang sama untuk berkontribusi dalam argumentasi dan menyampaikan argumennya; c). Akses universal dan sama (equal) atas partisipasi harus dinikmati oleh semua pihak tanpa adanya kemungkinan represi secara halus maupun kasar. Lihat: Jurgen Habermas, Op. cit., hlm. 89.

44 Ibid., hlm. 221. 
empiris menunjukkan bahwa kepercayaan publik dapat mempengaruhi persepsi masyarakat awam tentang resiko dan manfaat dari sebuah keputusan publik, yang pada gilirannya juga akan meningkatkan penerimaan masyarakat atas keputusan tersebut. ${ }^{45}$ Karena itulah, kepercayaan publik terhadap pengambil keputusan, atau mereka yang mengontrol teknologi misalnya, dapat mempengaruhi persepsi dan penerimaan publik tentang keputusan/teknologi yang diambil. ${ }^{46}$

Secara substantif, partisipasi dalam pengambilan keputusan dapat dibenarkan karena pengambilan keputusan melalui dialog dan diskursus dianggap dapat memperbaiki kualitas keputusan. ${ }^{47}$ Dalam hal ini, proses deliberasi merupakan jaminan bahwa pembuatan keputusan, terutama ketika terdapat ketidakpastian ilmiah, telah diambil secara demokratis. ${ }^{48}$
Lebih jauh lagi, proses demokratisasi juga dapat membuat keputusan dan proses pengambilan keputusan memiliki dasar yang lebih kuat, baik secara sosial maupun secara ilmiah. Alasan seperti ini yang oleh Stirling disebut sebagai pembenaran substantif bagi partisipasi, di mana partisipasi dianggap sebagai "a means to consider broader issues, questions, conditions, causes or possibilities that might otherwise be missed in appraisal." 49

Pada tahun 1969, Arstein mempublikasikan sebuah artikel yang memuat pembagian partisipasi, yang disebutnya sebagai "tangga partisipasi" (a ladder of participation). Dalam tulisan ini, Artstein membedakan partisipasi ke dalam delapan tingkat partisipasi, serta mengurutkannya mulai dari bentuk non-partisipasi (di dasar tangga) sampai pada partisipasi yang maling maksimum (di puncak tangga). ${ }^{50}$

45 Kajian Siegrist dan Cvetkovich, misalnya, menunjukkan adanya korelasi yang kuat antara persepsi publik atas resiko dan manfaat dari teknologi tertentu. Partisipan yang memandang sebuah teknologi sebagai bermanfaat, cenderung untuk memiliki persepsi bahwa teknologi tersebut memiliki resiko yang rendah. Sebaliknya, mereka yang memiliki persepsi bahwa sebuah teknologi memiliki sedikit manfaat, cenderung memiliki persepsi bahwa teknologi tersebut memilki resiko yang tinggi. Namun demikian, kajian dari Siegrist dan Cvetkovich pun menunjukkan bahwa korelasi tersebut berkurang pada saat kepercayaan (trust) dikontrol, atau jika partisipan menganggap dirinya memiliki pengetahuan yang memadai tentang resiko dan manfaat dari sebuah teknologi.

Dengan merujuk pada Alhakami dan Slovic, Siegrist dan Cvetkovich menduga bahwa relasi terbalik antara persepsi tentang resiko dan manfaat dapat terjadi karena adanya dorongan untuk berpikir secara konsisten, sehingga orang cenderung untuk menganggap sesuatu yang memiliki resiko tinggi akan memiliki manfaat yang rendah, dan sebaliknya. Lihat: Michael Siegrist dan George Cvetkovich, "Perception of Hazards: The Role of Social Trust and Knowledge", Risk Analysis, Vol. 20(5), 2000, hlm. 714. Kajian Siegrist dan Cvetkovich sendiri bertujuan untuk menjelaskan faktor lain yang mempengaruhi hubungan antara persepsi tentang resiko dan manfaat dari sebuah keputusan, yaitu kepercayaan publik.

46 Sebuah penelitian empiris lain dari Siegris terkait hubungan antara kepercayaan dan persepsi/penerimaan publik atas dari bioteknologi menunjukkan bahwa kepercayaan merupakan faktor terpenting yang akan mempengeruhi persepsi publik atas resiko/manfaat dari bioteknologi. Karena persepsi akan resiko/manfaat ini secara langsung akan mempengaruhi penerimaan publik atas bioteknologi, Siegriest menyimpulkan bahwa pada akhirnya kepercayaan publik akan pula mempengaruhi penerimaan publik atas bioteknologi. Lihat: Michael Siegrist, "The Influence of Trust and Perceptions of Risks and Benefits on the Acceptance of Gene Technology", Risk Analysis, Vol. 20(2), 2000, hlm. 201.

47 Elizabeth Fisher dan Ronny Harding, "The Precautionary Principle: Towards a Deliberative, Transdisciplinary Problem-Solving Process", dalam Elizabeth Fisher dan Ronny Harding, 1999, Perspective on the Precautionary Principle, The Federation Press, Sydney, hlm. 291.

48 Fisher berpendapat bahwa ketika terdapat ketidakpastian ilmiah, keputusan tidak lagi dapat didasarkan sepenuhnya pada landasan ilmiah, sehingga proses pengambilan keputusan haruslah dilakukan secara terbuka dan kolektif, serta telah mempertimbangkan semua isu yang menjadi perhatian. E.C. Fisher, "The Precautionary Principle as a Legal Standard for Public Decision-Making: the Role of Judicial and Merits Review in Ensuring Reasoned Deliberation", dalam R. Harding and E. Fisher, 1999, Perspectives on the Precautionary Principle, The Federation Press, Sydney, hlm. 90-91.

49 Andy Stirling, Op. cit., hlm. 223.

Hal senada juga disampaikan oleh Vos. Menurutnya, partisipasi publik dalam pembuatan kebijakan tidak hanya berpotensi meningkatkan kepercayaan dan penerimaan publik kepada keputusan yang diambil, tetapi juga berperan untuk menyediakan informasi yang berguna bagi peningkatan kualitas keputusan yang diambil. Lihat: E.Vos, "Overcoming the Crisis of Confidence: Risk Regulation in an Enlarged European Union”, inauguration speech, University of Maastrich, 2004, hlm. 18.

Dalam fungsi terakhir ini, Vos menyatakan partisipasi public dapat memfasilitasi munculnya input dari publik, yang pada gilirinnya akan mampu untuk menyediakan "relevant knowledge, values, or questions, which scientists have neglected." Ibid., hlm. 19.

50 Lihat: Sherry R. Arnstein, “A Ladder Of Citizen Participation”, Journal of the American Institute of Planners, Vol. 35(4), 1969. Sebagai perbandingan, dapat dirujuk bentuk-bentuk partisipasi publik dari Callahan, yang didasarkan pada fungsi atau peran yang berbeda antara warga dan administrator (pejabat administrasi). Dengan cara ini Callahan menghasilkan delapan bentuk partisipasi, yaitu: a). Model warga 
Pada bagian dasar, terdapat tingkat non-partisipasi dalam bentuk manipulasi (manipulation) dan terapi (therapy). ${ }^{51}$ Di atas tipe non-partisipasi, Arstein menjabarkan tingkat partisipasi yang minim/tokenisme (degrees of tokenism) yang terdiri dari bentuk pemberian informasi (informing), konsultasi (consultation), dan plakasi (placation). ${ }^{52}$ Tahapan partisipasi tertinggi adalah kekuasaan warga (citizen power), berupa kemitraan (partnership), pendelegasian kekuasaan (delegated power), dan kontrol

sebagai subyek, administrator sebagai penguasa (Citizen as subject - Administrator as ruler). Dalam model ini administrator bertindak sebagai pemberi perintah kepada warga masyarakat; sedangkan warga masyarakat bertindak sebagai pihak yang diperintah dan harus menuruti perintah tersebut. b). Model warga sebagai pemilih, administrator sebagai pelaksana (Citizen as voter - Administrator as implementer). Model ini sejalan dengan sistem demokrasi perwakilan. Dalam sistem ini, administrator bertanggung jawab kepada pejabat yang dipilih oleh warga masyarakat sebagai orang yang paling tepat untuk mewakili kepentingannya. c). Model warga sebagai klien, administrator sebagai ahli (Citizen as client - Administrator as expert). Dalam model ini, pejabat administrasi bertindak sebagai pakar yang bertugas untuk mengambil keputusan rasional berdasarkan netralitas mereka; sedangkan warga masyarakat dianggap sebagai klien yang menggunakan keahlian dari pejabat administrasi. d). Model warga sebagai konsumen, administrator sebagai profesional/enterprener (Citizen as customer - Administrator as professional/entrepreneur). Dalam model partisipasi ini warga masyarakat bertindak seperti konsumen, sedangkan administrator bertindak sebagai profesional yang menyediakan pelayanan bagi konsumen. Sebagai konsumen, warga masyarakat bersikap pasif; sedangkan sebagai profesional, administrator bersikap responsif dan berorientasi pada kepuasan konsumen (dalam hal ini warga masyarakat). e). Model warga sebagai warga negara, administrator sebagai pelayan publik (Citizen as citizen - Administrator as public servant). Model partisipasi ini menempatkan pejabat sebagai pelayan sekaligus pihak yang memberdayakan warga masyarakat melalui pengelolaan organisasi publik dan implementasi kebijakan publik. f). Model warga sebagai ko-produsen, administrator sebagai ko-produsen (Citizen as coproducer Administrator as co-producer). Model ini merefleksikan kolaborasi ideal sebagai ko-produser, di mana warga dan administrator bekerja sama untuk memecahkan masalah publik, sehingga model ini mengandaikan kemitraan yang aktif dan pembagian tanggung jawab. g). Model warga sebagai investor, administrator sebgai perantara/broker (Citizen as investor - Administrator as broker). Model ini mengasumsikan warga masyarakat sebagai investor dan pemegang saham publik; sedangkan administrator merupakan agen yang akan mengelola "saham" tersebut untuk sebesar-besarnya kesejahteraan "investor". h). Model warga sebgai pemilik, administrator sebagai pegawai (Citizen as owner - Administrator as employee). Dalam model ini, warga masyarakat adalah pemilik kontrol; sedangkan administrator merupakan pihak yang harus taat dan tunduk pada keputusan warga. Lihat: Kathe Callahan, 2007, Elements of Effective Governance: Measurement, Accountability, and Participation, Taylor and Francis, New York, hlm. 185-187.

Selain dari tipe partisipasi di atas, terdapat pula kriteria atau ciri partisipasi dari partisipasi publik yang dikembangkan oleh Asosiasi Internasional untuk Partisipasi Publik (The International Association for Public Participation, IAP2), sebagaimana dikemukakan oleh Creighton, sebagai berikut: a). Publik harus memiliki kesempatan untuk menyampaikan pendapatnya terkait keputusan yang akan berpengaruh pada mereka; b). Partisipasi publik harus pula meliputi jaminan bahwa pendapat/kontribusi masyarakat akan mempengaruhi keputusan yang diambil; c). Proses partisipasi publik harus mampu mengkomunikasikan dan mengungkapkan kepentingan atau kebutuhan dari para pihak; d). Proses partisipasi publik harus berupaya untuk memfasilitasi keterlibatan dari mereka yang berpotensi terkena dampak dari sebuah keputusan/tindakan; e). Proses partisipasi publik harus pula melibatkan publik dalam penentuan cara bagaimana publik akan berpartisipasi; f). Proses partisipasi publik harus menyediakan informasi yang dibutuhkan publik untuk menjamin bahwa partisipasi mereka akan berarti; dan g). Proses partisipasi publik juga harus mengkomunikasikan kepada publik bagaimana masukan dari publik telah mempengaruhi keputusan yang diambil. Lihat: James L. Creighton, 2005, The Public Participation Handbook: Making Better Decisions through Citizen Involvement, CA:Jossey-Bass, San Fransisco, hlm. 7-8.

51 Dalam manipulasi, masyarakat ditempatkan hanya sebagai alat stempel untuk membenarkan apa yang diputuskan oleh pengambil keputusan. Dalam hal ini pengambil keputusan, misalnya, memanipulasi dukungan masyarakat untuk menunjukkan adanya keterlibatan masyarakat, padahal keputusan yang diambil tersebut tidak pernah didiskusikan sebelumnya dengan masyarakat. Dengan demikian, masyarakat direkayasa sedemikian rupa sehingga hanya berfungsi untuk mendukung keputusan yang diambil. Dalam bentuk terapi, ketidakberdayaan masyarakat dianggap sebagai penyakit, sehingga masyarakat perlu "disembuhkan" dari penyakit ini. Dalam bentuk terapi, terdapat kegiatan yang melibatkan masyarakat, tetapi hal ini bukanlah bentuk dari partisipasi publik dalam pengambilan keputusan, karena kegiatan ini dilakukan sebagai upaya untuk melakukan "terapi" atau untuk "menyembuhkan" masyarakat.

Lihat: Sherry R. Arnstein, Op. cit., hlm. 218.

52 Dalam tingkat tokenisme ini masyarakat dimungkinkan untuk mengetahui informasi, bahkan untuk menyampaikan pendapatnya, tetapi tidak memiliki kontrol untuk menjamin bahwa pendapatnya itu akan mempengaruhi keputusan. Pemberian informasi (informing) dianggap sebagai langkah awal yang penting dalam partisipasi publik yang genuine. Dalam hal ini, masyarakat diberitahukan informasi mengenai hak dan tanggung jawab mereka, serta pilihan-pilihan yang tersedia. Namun demikian, pada tahapan ini, pemberian informasi seringkali bersifat sepihak dan satu arah, sehingga masyarakat sebenarnya memiliki kesempatan yang kecil untuk mempengaruhi hasil akhir keputusan agar sesuai dengan kepentingannya. Bentuk konsultasi biasanya dilakukan dalam bentuk survey, pertemuan tetangga/warga, atau pertemuan dengar pendapat (public hearings). Sama seperti pemberian informasi, konsultasi juga dianggap merupakan langkah penting menuju partisipasi publik yang nyata. Akan tetapi apabila partisipasi hanya dilakukan sebatas konsultasi, maka partisipasi menjadi terbatas. Dalam hal ini, partisipasi hanya dibuktikan melalui seberapa banyak orang yang datang ke dalam pertemuan, dan bukan diukur besarnya pengaruh dari pertemuan/ konsultasi terhadap keputusan yang diambil. Bentuk partisipasi lainnya dalam kelompok tokenisme adalah penentraman (placation). Dalam bentuk partisipasi ini, terdapat orang-orang tertentu yang diangkat untuk duduk sebagai wakil masyarakat di dalam komisi atau otoritas tertentu. Dalam kondisi ini, masyarakat (atau wakilnya) dapat mengemukakan pendapatnya, tetapi keputusan tetap berada di tangan pejabat pengambil keputusan. Di samping itu, kualitas partisipasi dalam bentuk penentraman juga akan dipengaruhi oleh kualitas bantuan teknis bagi masyarakat untuk mengartikulasikan kepentingan mereka dan oleh sejauh mana masyarakat berhasil mengorganisir dirinya untuk mewujudkan aspirasi mereka. Dengan kata lain, keberadaan wakil masyarakat tidak menjamin bahwa partisipasi telah terjadi. Apabila wakil tersebut tidak bertanggung jawab kepada masyarakat, atau apabila wakil tersebut hanyalah minoritas dibandingkan dengan elit kekuasaan yang memiliki porsi mayoritas, maka suara wakil tersebut akan dengan mudah dikesampingkan. Lihat Ibid., hlm. 219-220. 
oleh warga (citizen control). ${ }^{53}$

Konteks Indonesia, pengakuan terhadap pentingnya proses pengambilan keputusan secara demokratis dan partisipasi publik sedini mungkin, dapat dilihat dari berbagai ketentuan, mulai dari ketentuan mengenai KLHS, izin lingkungan, Amdal, sampai dengan pemberian izin usaha. Di samping keterlibatan terkait dengan perizinan, masyarakat pun memiliki peran dalam hal pengawasan dan penegakan hukum, dengan difasilitasinya pengaduan masyarakat dan hak gugat. Contoh lain dari partisipasi publik dapat dilihat pada UU No. 26 tahun 2007 tentang Penataan Ruang. Dalam hal ini, UU memberikan ruang kepada masyarakat untuk berpartisipasi dalam penyusunan rencana tata ruang, pemanfaatan ruang, dan pengendalian pemanfaatan ruang. ${ }^{54}$ Untuk selanjutnya, ketentuan tentang partisipasi publik dalam penataan ruang diatur secara lebih terperinci di dalam PP No. 68 tahun 2010 tentang Bentuk dan Tata Cara Peran Masyarakat dalam Penataan Ruang.

\section{b. Hak atas Informasi}

Keadilan prosedural selain terkait aspek partisipasi dalam pengambilan keputusan juga terkait dapat pula dengan aspek perlindungan hak atas informasi. UU
No. 32 tahun 2009 melihat bahwa pelibatan masyarakat dalam pengambilan keputusan mensyaratkan pada adanya pemberian informasi transparan dan lengkap sebelum sebuah kegiatan dilaksanakan. ${ }^{55}$ Lebih dari itu, UU No. 32 tahun 2009 juga mengakui bahwa akses atas informasi merupakan hak setiap orang. ${ }^{56}$ Atas dasar inilah maka UU No. 32 tahun 2009 pada satu sisi telah memberikan mandat kepada Pemerintah untuk mengembangkan sistem informasi lingkungan hidup, yang harus dibuat terbuka bagi masyarakat. Sistem informasi ini setidaknya memuat informasi mengenai status lingkungan hidup, peta rawan lingkungan hidup, dan informasi lingkungan hidup lainnya. ${ }^{57}$ Pada sisi lain, UU No. 32 tahun 2009 juga membebankan kewajiban kepada pelaku usaha/kegiatan untuk memberikan informasi yang terkait dengan perlindungan dan pengelolaan lingkungan hidup secara benar, akurat, terbuka, dan tepat waktu. ${ }^{58}$ Mereka yang dianggap telah menyampaikan informasi palsu, menyesatkan, menghilangkan informasi, merusak informasi, atau memberikan keterangan yang tidak benar perlindungan dan pengelolaan lingkungan hidup diancam dengan sanksi pidana. ${ }^{59}$

53 Di dalam kemitraan, kekuasaan didistribusikan antara warga dan penguasa melalui negosiasi. Warga dan penguasa menyetujui untuk berbagi tanggung jawab dalam perencanaan dan pengambilan keputusan, misalnya melalui pembentukan komite bersama atau melalui mekanisme tertentu dalam rangka menyelesaikan hambatan. Menurut Arstein, kemitraan ini bekerja secara efektif ketika pemimpin dari warga merupakan orang yang dapat bertanggung jawab (accountable), atau ketika warga memiliki cukup uang untuk menggaji pemimpin mereka atau membayar orang yang akan membantu kepentingan mereka (seperti pengacara). Di dalam pendelegasian kekuasaan, warga masyarakat memiliki posisi atau kekuasaan yang dominan dalam pengambilan keputusan. Hal ini terwujud, misalnya, ketika wakil warga masyarakat memiliki porsi atau suara terbanyak di dalam komisi. Bentuk lain dari pendelegasian kekuasaan juga dapat tercipta dengan adanya komisi-komisi paralel yang masing-masing mewakili kepentingan masyarakat dan pengambil keputusan, tetapi komisi yang mewakili kepentingan masyarakat memiliki hak veto jika hasil dari komisi-komisi tersebut memiliki perbedaan. Pada tingkat paling tinggi, partisipasi akan berbentuk kontrol warga (citizen control). Dalam tingkat partisipasi ini, masyarakat sedikit banyak memiliki kekuasaan atau kontrol untuk menjamin bahwa mereka dapat mengatur program atau menjalankan lembaga tertentu, memiliki kekuasaan atas kebijakan yang diambil, dan dapat melakukan perundingan-perundingan terkait kondisi tertentu. Lihat: Ibid., hlm. 221-223.

54 Pasal 65 Undang-Undang Nomor 26 Tahun 2007 tentang Penataan Ruang (Lembaran Negara Republik Indonesia tahun 2007 Nomor 68 , Tambahan Lembaran Negara Republik Indonesia Nomor 4725).

55 Pasal 26 ayat (2) Undang-Undang Nomor 32 tahun 2009 tentang Perlindungan dan Pengelolaan Lingkungan Hidup (Lembaran Negara Republik Indonesia Tahun 2009 Nomor 140, Tambahan Lembaran Negara Republik Indonesia Nomor 5059).

56 Pasal 65 ayat (2) Undang-Undang Nomor 32 tahun 2009 tentang Perlindungan dan Pengelolaan Lingkungan Hidup (Lembaran Negara Republik Indonesia Tahun 2009 Nomor 140, Tambahan Lembaran Negara Republik Indonesia Nomor 5059).

57 Pasal 62 Undang-Undang Nomor 32 tahun 2009 tentang Perlindungan dan Pengelolaan Lingkungan Hidup (Lembaran Negara Republik Indonesia Tahun 2009 Nomor 140, Tambahan Lembaran Negara Republik Indonesia Nomor 5059).

58 Pasal 68 Undang-Undang Nomor 32 tahun 2009 tentang Perlindungan dan Pengelolaan Lingkungan Hidup (Lembaran Negara Republik Indonesia Tahun 2009 Nomor 140, Tambahan Lembaran Negara Republik Indonesia Nomor 5059).

59 Pasal 113 Undang-Undang Nomor 32 tahun 2009 tentang Perlindungan dan Pengelolaan Lingkungan Hidup (Lembaran Negara Republik Indonesia Tahun 2009 Nomor 140, Tambahan Lembaran Negara Republik Indonesia Nomor 5059). 


\section{c. Hak Gugat}

Aspek terakhir yang perlu dibahas dalam keadilan prosedural adalah aspek hak gugat. Secara konvensional, hukum acara perdata Indonesia mengakui adanya hak gugat perorangan, sehingga hak ini dapat digunakan pula untuk kasus lingkungan hidup. Lebih dari itu, UU No. 32 tahun 2009 mengakui hak gugat LSM lingkungan, ${ }^{60}$ hak gugat masyarakat (class action) ${ }^{61}$ hak gugat Pemerintah, ${ }^{62}$ dan hak gugat setiap orang untuk melakukan gugatan terhadap keputusan tata usaha negara. ${ }^{63}$ Selain itu, praktek di pengadilan juga menunjukkan adanya pengakuan terhadap hak gugat warga negara (citizen lawsuits, CLS). ${ }^{64}$

\section{Keadilan Lingkungan sebagai Keadilan Sosial}

Berdasarkan taksonomi Kuehn, keadilan lingkungan dapat pula diartikan sebagai keadilan sosial, yaitu cabang dari keadilan yang akan mendorong kita untuk melakukan upaya terbaik guna mencapai tatanan masyarakat yang mampu memenuhi kebutuhan hidup masyarakat. Dalam hal ini, keadilan sosial meminta bahwa setiap anggota masyarakat memiliki sumber daya dan kekuasaan yang cukup untuk hidup secara layak sebagai manusia. ${ }^{65}$

Keadilan lingkungan sebagai keadilan sosial juga dapat dilihat dari pandangan yang menyatakan bahwa upaya pengentasan kemiskinan merupakan bagian yang tidak terpisahkan dari upaya perlindungan dan pengelolaan lingkungan. Dalam hal ini, Langhelle menegaskan bahwa laporan WCED, Our Common Future, mengindikasikan adanya hubungan empiris dan fungsional antara keadilan sosial dan pembangunan berkelanjutan. Hal ini terlihat dari pandangan Komisi, bahwa pada satu sisi kemiskinan merupakan penyebab dari banyak persoalan lingkungan ("major cause and effect of global environmental problems"), dan pada sisi lain pengentasan kemiskinan merupakan prasyarat bagi pembangunan yang ramah lingkungan ("precondition for environmentally sound development"). ${ }^{66}$

60 Pasal 92 Undang-Undang Nomor 32 tahun 2009 tentang Perlindungan dan Pengelolaan Lingkungan Hidup (Lembaran Negara Republik Indonesia Tahun 2009 Nomor 140, Tambahan Lembaran Negara Republik Indonesia Nomor 5059).

61 Pasal 91 Undang-Undang Nomor 32 tahun 2009 tentang Perlindungan dan Pengelolaan Lingkungan Hidup (Lembaran Negara Republik Indonesia Tahun 2009 Nomor 140, Tambahan Lembaran Negara Republik Indonesia Nomor 5059).

62 Pasal 90 Undang-Undang Nomor 32 tahun 2009 tentang Perlindungan dan Pengelolaan Lingkungan Hidup (Lembaran Negara Republik Indonesia Tahun 2009 Nomor 140, Tambahan Lembaran Negara Republik Indonesia Nomor 5059).

63 Pasal 93 Undang-Undang Nomor 32 tahun 2009 tentang Perlindungan dan Pengelolaan Lingkungan Hidup (Lembaran Negara Republik Indonesia Tahun 2009 Nomor 140, Tambahan Lembaran Negara Republik Indonesia Nomor 5059).

64 Menurut Lampiran dari Keputusan Ketua Mahkamah Agung RI No. 36/KMA/SK/II/2013 tentang Pemberlakuan Pedoma Penanganan Perkara Lingkungan Hidup, persyaratan gugatan CLS: a). Penggugat adalah satu orang atau lebih WNI, dan bukan badan hukum; b). Tergugat adalah pemerintah dan/atau lembaga negara; c). Dasar gugatan adalah untuk kepentingan umum; d). Obyek gugatan adalah pembiaran atau tidak dilaksanakannya kewajiban hukum; e). kewajiban melakukan Notifikasi/somasi bagi calon penggugat dalam waktu 60 hari kerja sebelum adanya gugatan. Notifikasi/somasi ini bertujuan untuk memberikan kesempatan kepada Pemerintah melaksanakan kewajiban hukumnya sebagaimana diminta atau dituntut oleh calon penggugat; f). Notifikasi/somasi harus ditembuskan ke ketua PN setempat.

Untuk kasus lingkungan hitup, putusan CLS dapat dilihat dalam Putusan PN Samarinda No.55/Pdt.G/2013/PN.Smda, 2014, Komari, dkk vs. Negara Republik Indonesia Cq. Pemerintah RI, dkk. yang dikuatkan oleh Putusan PT Samarinda No. 138/PDT/2015/PT.SMR. Gugatan ini adalah gugatan CLS terkait perubahan iklim pertama di Indonesia. Pengadilan mengabulkan gugatan penggugat dan menghukum Pemerintah untuk, di antaranya, mengatur kembali kebijakan umum terkait pertambangan batu bara dan melakukan evaluasi terhadap seluruh izin pertambangan batu bara yang telah dikeluarkan.

Gugatan lain terkait CLS dapat dilihat dalam Putusan PN Palangkaraya No. 118/Pdt.G/LH/2016/PN Plk, 2017, Arie Rompas, dkk. v. Negara Republik Indonesia Cq. Presiden Republik, dkk. Gugatan ini adalah gugatan CLS pertama terkait kebakaran hutan/lahan dan kabut asap. Pengadilan mengabulkan gugatan penggugat dan memerintahkan tergugat untuk melakukan kegiatan, di antaranya, melakukan peninjauan ulang dan merevisi izin-izin usaha pengelolaan hutan dan perkebunan, melakukan penegakan hukum lingkungan, membuat kebijakan umum terkait langkah pencegahan dini, penanggulangan dan pemulihan korban kebakaran hutan dan lahan serta pemulihan lingkungan, serta mendirikan rumah sakit khusus paru dan penyakit lain akibat pencemaran udara asap.

65 Kuehn menyatakan pula bahwa prinsip keadilan lingkungan sebagai keadilan sosial meminta adanya alternatif sistem ekonomi yang mampu memberikan kontribusi pada pembangunan yang ramah lingkungan; mendukung pembebasan masyarakat secara politik, ekonomi, dan budaya; memajukan kebijakan yang didasarkan pada saling menghormati, keadilan bagi semua orang, dan tanpa diskriminasi; mendorong terjadinya pemulihan lingkungan baik di perkotaan maupun desa; menghormati integritas budaya masyarakat; dan menyediakan akses bagi semua masyarakat atas sumber daya yang dimiliki oleh masyarakat. Lihat: Robert Kuehn, Op. cit., hlm. 10698-10699.

66 Oluf Langhelle, Op. cit., hlm. 299-300. 


\section{Penutup}

Keadilan intra generasi dapat dilihat dari setidaknya empat perspektif, yaitu keadilan lingkungan sebagai keadilan distributif, korektif, prosedural, dan sosial. Keadilan distributif menginginkan adanya alokasi yang lebih adil bagi akses dan manfaat dari sumber daya lingkungan, bagi manfaat perlindungan lingkungan, dan bagi biaya perlindungan lingkungan. Keadilan korektif menginginkan adanya perangkat hukum yang memungkinkan mereka yang telah menyebabkan kerugian untuk mengkoreksi dan menghilangkan kerugian yang ditimbulkannya. Keadilan prosedural menginginkan adanya proses yang mampu menjamin bahwa distribusi akan dilakukan secara adil. Secara umum, keadilan prosedural ini dapat diwujudkan melalui adanya pengakuan mengenai hak untuk berpartisipasi dalam pengambilan keputusan, hak atas informasi, dan hak gugat. Sedangkan keadilan sosial merupakan konsep keadilan yang melihat bahwa persoalan lingkungan merupakan persoalan yang lahir dari ketimpangan sosial dan kemiskinan, sehingga pengentasan kemiskinan dan penghilangan kondisi ketidakadilan sosial merupakan bagian integral dari upaya perlindungan dan pengelolaan lingkungan hidup.

\section{DAFTAR PUSTAKA}

\section{A. Buku}

Adler, John dan Wilkinson, David, 1999, Environmental Law and Ethics, Mac Millan Press, London.

Beder, Sharon, 2006, Environmental Principles and Policies: An Interdiciplinary Introduction Earthscan, New York.

Boyle, Alan dan Birnie, Patricia, 2002, International Law and the Environment $2^{\text {nd }} \mathrm{ed}$., Oxford University Press, Oxford.

Callahan, Kathe, 2007, Elements of Effective Governance: Measurement, Accountability, and Participation, Taylor and Francis, New York.

Creighton, James L., 2005, The Public Participation Handbook: Making Better Decisions through Citizen Involvement, CA:Jossey-Bass, San Fransisco.

Dworkin, Ronald, 1978, Taking Rights Seriously, Harvard University Press, Cambridge.

Faure, Michael, 2001, Environmental Law and Economics, Maastricht University, Maastricht.

Faure, Michael dan Skogh, Goran, 2003, The Economic Analysis of Environmental Policy and Law: An Introduction, Edward Elgar, Cheltenham.
Habermas, Jurgen, 2007, Moral Consciousness and Communicative Action, Polity Press, Cambridge.

Hunter, D., et al., 1998, International Environmental Law and Policy, Foundation Press, New York.

Mansfield, Edwin, 1983, Principles of Microeconomics 4th ed., W.W. Norton and Company, New York.

Pearce, D.W., dan Turner, R.K., 1990, Economics of Natural Resources and the Environment, Johns Hopkins University Press, Baltimore.

Pindyck, R.S. and Rubinfield, D.L., 2001, Microeconomics 5th ed., Prentice Hall, New York.

Rawls, John, 1999, A Theory of Justice, Belknap Press of Harvard University Press, Cambridge.

Sands, Philippe, 1995, Principles of International Environmental Law: Vol. 1, Frameworks, Standards, and Implementation, Manchester University Press, Manchester.

Solberg, Eric J., 1982, Intermediate Microeconomics, Tex: Business Publication, Plano.

\section{B. Artikel Jurnal}

Arnstein, Sherry R., "A Ladder Of Citizen Participation", Journal of the American 
Institute of Planners, Vol. 35(4), 1969.

Collin, Robert W., "Environmental Justice in Oregon: It's The Law", Environmental Law, Vol. 38, 2008.

French, Duncan, "Developing States and International Environmental Law:

The Importance of Differentiated Responsibilities", The International and Comparative Law Quarterly, Vol. 49(1), 2000.

Ikeme, Jekwu, "Equity, Environmental Justice and Sustainability: Incomplete Approaches in Climate Change Politics" Global Environmental Change, Vol. 13, 2003.

Kaswan, Alice, "Environmental Justice: Bridging the Gap between Environmental Laws and 'Justice",, The American University Law Review, Vol. 47, 1997.

Kuehn, Robert R., “A Taxonomy of Environmental Justice", Environmental Law Reporter, Vol. 30,2000

Langhelle, Oluf, "Sustainable Development and Social Justice: Expanding the Rawlsian Framework of Global Justice", Environmental Values, Vol. 9, No. 3, 2000.

Millner, Felicity, "Access to Environmental Justice", Deakin Law Review, Vol. 16, No.1, 2011.

Siegrist, Michael, "The Influence of Trust and Perceptions of Risks and Benefits on the Acceptance of Gene Technology", Risk Analysis, Vol. 20(2), 2000.

Siegrist, Michael dan Cvetkovich, George, "Perception of Hazards: The Role of Social Trust and Knowledge", Risk Analysis, Vol. 20(5), 2000.

Solum, Lawrence B., "Procedural Justice", Southern California Law Review, Vol. 78, 2004.

Weiss, Edith Brown, "Common but Differentiated Responsibilities in Perspective", Proceedings of the Annual Meeting (American Society of International Law, Vol. 96, 2002.

\section{Artikel dalam Antologi}

Boyle, Alan, "Economic Growth and Protection of the Environment: Impact of International Law and Policy", dalam Boyle, Alan, 1994, Environmental Regulation and Economic Growth, Clarendon Press, London.

Bullard, Robert D., "Environmnetal Justice for All”, dalam Bullard, Robert D., 1994, Environmental Justice and Communities of Color, Sierra Club Books, San Fransisco.

Fisher, Elizabeth dan Harding, Ronny, "The Precautionary Principle: Towards a Deliberative, Transdisciplinary ProblemSolving Process", dalam Fisher, Elizabeth dan Harding, Ronny,1999, Perspective on the Precautionary Principle, The Federation Press, Sydney.

Fisher, E.C., "The Precautionary Principle as a Legal Standard for Public DecisionMaking: the Role of Judicial and Merits Review in Ensuring Reasoned Deliberation", dalam Harding, R. dan Fisher, E., 1999, Perspectives on the Precautionary Principle, The Federation Press, Sydney.

Magraw, Daniel Barstow dan Hawke, Lisa D., "Sustainable Development", dalam Bodansky, Daniel, et al., 2007, The Oxford Handbook of International Environmental Law, Oxford University Press, Oxford.

Stirling, Andy, "Opening up or Closing down? Analysis, Participation and Power in the Social Appraisal of Technology", dalam M. Leach, et al., 2005, Science and Citizens: Globalization and the Challenge of Engagement, Zed Books, London.

Syfers, James, "Human Rights versus Classical Liberalism: A Study in the Theory of Value", dalam Anton, Anatole, et al., 2000, Not for Sale: In Defense of Public Goods, Westview Press, Boulder.

\section{Peraturan Perundang-Undangan}

Undang-Undang Nomor 26 Tahun 2007 tentang 
Penataan Ruang (Lembaran Negara Republik

Indonesia tahun 2007 Nomor 68, Tambahan

Lembaran Negara Republik Indonesia

Nomor 4725).

Undang-Undang Nomor 32 tahun 2009 tentang

Perlindungan dan Pengelolaan Lingkungan

Hidup (Lembaran Negara Republik Indonesia

Tahun 2009 Nomor 140, Tambahan Lembaran

Negara Republik Indonesia Nomor 5059).

\section{E. Lain-Lain}

Keputusan Ketua Mahkamah Agung RI No. 36/

KMA/SK/II/2013 tentang Pemberlakuan

Pedoma Penanganan Perkara Lingkungan Hidup

Putusan PN Samarinda No.55/Pdt.G/2013/

PN.Smda, 2014, Komari, dkk vs. Negara Republik Indonesia Cq. Pemerintah RI, dkk
Putusan PN Palangkaraya No. 118/Pdt.G/LH/2016/ PN Plk, 2017, Arie Rompas, dkk. v. Negara Republik Indonesia Cq. Presiden Republik, $d k k$

Preambular paragraph, UNGA A/RES/44/228, 22 December 1989.

The 1992 UN Framework Convention on Climate Change, 9 May 1992 (in force 21 March 1994), 1771 UNTS 107, 31 ILM 849 (1992)

Montreal Protocol on Substances that Deplete the Ozone Layer as Either Adjusted and/ or Amended in London 1990, Copenhagen 1992, Vienna 1995, Montreal 1997.

The Cancun Agreements: Outcome of the Work of the Ad Hoc Working Group on Long-term Cooperative Action under the Convention, FCCC/CP/2010/7/Add.1, Decision 1/ CP16. 